\title{
FOLYTONOS ANYAGTOVÁBBÍTÁSÚ MIKROHULLÁMÚ KEZELŐEGYSÉG FEJLESZTÉSE
}

\author{
Kovács Róbertné V.P. ${ }^{1}$ - Beszédes Sándor ${ }^{2}$ - Dr. PhD. Ludányi Lajos ${ }^{3}$ - \\ Prof. Dr. Hodúr Cecilia ${ }^{4}-$ Prof. Dr. Szabó Gábor ${ }^{5}$ \\ 1. tudományos munkatárs, Szegedi Tudományegyetem, Mérnöki Kar, Müszaki Intézet \\ 2. tanársegéd, Szegedi Tudományegyetem, Mérnōki Kar, Folyamatmérnőki Intézet \\ 3. tudományos munkatárs, Szegedi Tudományegyetem, Mérnöki Kar, Folyamatmérnőki Intézet \\ 4. egyetemi tanár, Szegedi Tudományegyetem, Mérnöki Kar, Folyamatmémöki Intézet \\ 5. egyetemi tanár, Szegedi Tudományegyetem, Mérnőki Kar, Folyamatmérnőki Intézet
}

\begin{abstract}
SUMMARY
Most branches in the food industry have a considerable wastewater output. The problem is not only the total amount of wastewater production, but also the high content of organic matter. Anaerobic digestion is an effective way of treating wastewater for yielding profitable biogas and alleviating environmental concerns. Pre-treatment of sludge to break down its complex structure can be used for enhancing anaerobic digestibility. Research group of the Department of Process Engineering at the University of Szeged has investigated the applicability and the efficiency of microwave pre-treatment for food industry sludge. The results showed that the microwave treatment of sludge solution resulted in higher biodegradability and enhanced biogas production as well. According to these results a continuous-flow microwave toroidal cavity resonator treating-system was developed.
\end{abstract}

Kulcsszavak: mikrohullám, szennyvíziszap, folyamatos üzemü, üregrezonátor

\section{BEVEZETÉS}

A nagy mennyiségben keletkező ipari és kommunális szennyvíz erősen környezetterhelö hatású. Tisztításuk során a szennyeződéseket különböző szeparációs eljárásokkal választják le szennyviziszap formájában. A keletkező iszapok kezelési technológiáinak fejlesztése müszaki, energetikai és környezetvédelmi szempontból is egyre hangsúlyosabb szerepet kap.

Az keletkező szennyvizek elsősorban magas szervesanyag tartalmuk miatt jelentenek veszélyt környezetünkre, de éppen a magas szervesanyag tartalmuk lebontásával válik lehetővé nagy mennyiségü biogáz előállítása. A korábbi évek gyakorlatában a biogázüzemek létesítésének és üzemeltetésének célja elsősorban a különböző hulladékok és melléktermékek ártalmatlanitása volt, az energiakinyerés hozadékként jelentkezett. Ez a tendencia azonban napjainkra az EU-ban is és hazánkban is alapvetően megváltozott: a "waste-to-energy" koncepció előtérbe kerülésével egyre inkább a biomassza alapú energia előállító létesítmények gazdaságos üzemeltetése a cél.

Ennek az elvnek megfelelỏen a biogáz termelés során, fontos szempont, hogy adott kiindulási anyagból minél nagyobb mennyiségủ hasznos terméket tudjunk előállitani.

A rothasztásra kerülő alapanyagok esetében a biológiai lebonthatóság mértéke a kihozatali mutatókra és a fermentáció időbeni lefutására egyaránt hatással van. A magas szervesanyag tartalmú szennyvizek elméletileg magas biológiai lebonthatósággal rendelkeznek, azonban a háztartásokból, a szennyviztisztítás, és a különbözỏ ipari technológiák alkalmazása során bekerülő nagy mennyiségủ mosó-, tisztító-, fertőtlenítőszer kedvezőtlenül befolyásolja a lebonthatóság mértékét, illetve növeli a lebontási időt. Ezen hatások kiküszöbölésére, ezzel a biogázkihozatal növelésére különböző előkezelés eljárásokat alkalmazhatunk, mint például termikus, kémiai és fizikai kezelések, vagy az enzimes előkezelések.

A mikrohullámú energiaközlés élelmiszeripari, vegyipari és környezetvédelmi alkalmazása néhány évtizedes múltra tekint vissza. Legfontosabb előnyei között tartják 
számon az intenzív hökeltő tulajdonságát, illetve összetett rendszerekben az eltérő dielektromos tulajdonságú komponensek esetében megfigyelhető szelektív felmelegitő képességét. (Szabó, G. et al. 2002)

A szennyvizek és azokból származó szennyvíziszapok mikrohullámú kezelésének vizsgálatával csak az utóbbi két évtizedben kezdtek el foglalkozni. Az első kísérletek elsősorban a patogén mikroorganizmusok számának csökkentésére irányultak. A későbbiekben vizsgálták az egyes szervesanyagok biológiai lebonthatóságának változását, illetve oxidációs eljárásokkal kombinálva a szervesanyag-eltávolítás hatékonyságára gyakorolt hatásait is.

A mikrohullámú sugárzásnak a kommunális szennyvíziszapokra való hatását vizsgálva megállapították, hogy mind a szervesanyagok vízoldhatósága (Eskicioglu et al., 2008), mind az illékony szerves vegyületek esetében (Pino-Jelcic et al., 2006) a mikrohullámú energiaközléssel nagyobb növekedés érhetö el, mint a hagyományos hőkezelési eljárásokkal. A szerves anyagoknak a lebontó mikroorganizmusok általi könnyebb hozzáférhetösége anaerob fermentáció során magasabb biogázhozamot eredményez (Eskicioglu et al., 2009), illetve felgyorsítja a lebontás ütemét (Guo et al., 2009).

Az eddigi tanulmányokban közölt adatok szakaszos üzemmódú berendezésben végzett kísérletekre vonatkoznak, folyamatos anyagtovábbítású kezelő berendezések üzemeltetési paramétereinek optimalizálására vonatkozó tapasztalatokkal nem rendelkezünk. A folyamatos üzemű mikrohullámú szennyviz kezelések esetében a folyamatszabályozására is használható dielektromos anyagi jellemzők (dielektromos állandó, veszteségi tényező) változásának egzakt nyomon követése, a paraméterek real-time meghatározására alkalmas mérési rendszerek sincsenek kidolgozva.

\section{FOLYAMATOS ANYAGTOVÁBBÍTÁSÚ MIKROHULLÁMÚ KEZELÖ RENDSZER}

\subsection{Elôzetes kísérletek az üzemeltetési paraméterek meghatározására}

A Szegedi Tudományegyetem Mérnöki Karának Folyamatmérnöki Intézetében Szabó Gábor professzor vezetésével müködő kutatócsoport folyamatos anyagtovábbítású toroidüregrezonátoros kisérleti berendezést fejlesztett ki. Mivel folyamatos üzemü mikrohullámú iszapkezelésre vonatkozó kísérleti és üzemeltetési tapasztalatok nem álltak rendelkezésre, ezért a biogáz képzödés fokozásához szükséges, optimális sugárzási energia meghatározásához szakaszos üzemü, változtatható magnetron-teljesitményủ berendezésen végzett előkísérletekre volt szükség. Ezen vizsgálatok eredményei azt mutatták, hogy a mikrohullámú előkezelésnek, akkor van jelentős hatása a biológiai lebonthatóságra, ha a besugárzott energia $500 \mathrm{~kJ}$ szint felett van. A besugárzott összes teljesítmény mellett, a fajlagos mikrohullámú teljesitmény $\left(\mathrm{Wg}^{-1}\right)$ másik meghatározó müveleti paraméter, amely mind a szervesanyagok vízoldhatóságának, mind az aerob és anaerob úton történö lebontásnak a mértékét és ütemét befolyásolja (Beszédes et al., 2010; Beszédes et al., 2011,a). A biológiai lebonthatóságra vonatkozó analitikai vizsgálati eredmények, valamit az anaerob fermentáció mértékének és ütemének meghatározására vonatkozó batch mezofil rothasztási tesztek eredményei is azt mutatták, hogy mind a húsipari, mind a tejipari iszapok elökezelésére a $0,5-2,5 \mathrm{Wg}^{-1}$ fajlagos teljesítmény értéktartományban besugárzott, $500-900 \mathrm{~kJ}$ energia esetén érhető el az energetikai szempontból is megfelelő biogázhozam. 


\subsection{A mikrohullámú kezelőrendszer ismertetése}

A szakaszos üzemmódú elő-kísérletek során megállapított fajlagos mikrohullámú teljesitményt és a közölt mikrohullámú energia érték tartományt figyelembe véve, kifejlesztésre került egy folyamatos anyagtovábbítású toroid-rezonátoros mikrohullámú szennyvíziszap-kezelő rendszer. A berendezés tartalmaz egy magnetront, amely $700 \mathrm{~W}$ beépített teljesítményủ, és $2450 \mathrm{MHz}$ frekvenciájú mikrohullám előállítására képes. A magnetron kimenő teljesítményét a hálózati feszültség szabályozásával tudjuk a kívánt értékre állitani. A magnetron a túlmelegedés elkerülése érdekében vízhütéssel van ellátva, valamint hőmérsékletérzékelőkkel lett felszerelve, és egy digitális kijelzőn folyamatosan ellenőrizhető a magnetron mindenkori hőmérséklete.

A magnetronhoz négyszögletes csőtápvonallal csatlakozik az üregrezonátorhoz (1. ábra), ahol egy spirálcsövön keresztül áramlik a kezelendő anyag.

1. ábra: Kifejlesztett toroid-rezonátoros mikrohullámú szennyviziszap-kezelö berendezés föbb méretei

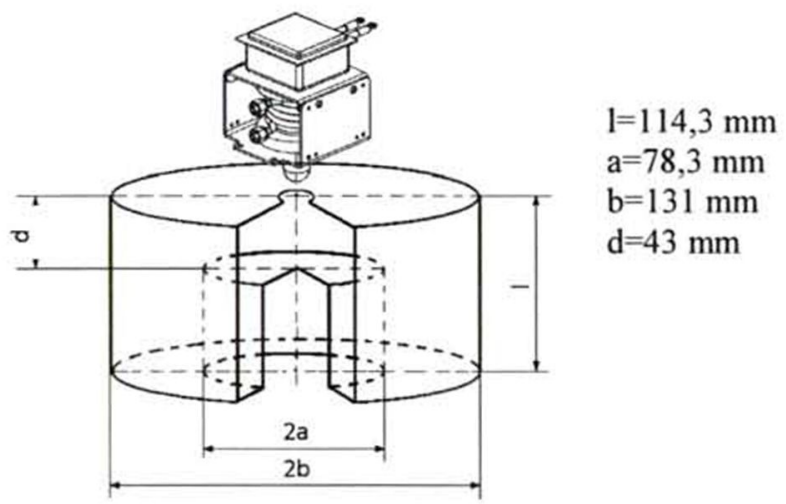

Forrás: Beszédes et. al., 2011,b

További föbb paraméterek:

a rezonáns hullámhossz:

$\lambda_{0}=\pi a \sqrt{\frac{2 \mathrm{I}}{d} \ln \frac{b}{a}}=\pi \cdot 7,83 \mathrm{~cm} \sqrt{\frac{2 \cdot 11,43 \mathrm{~cm}}{4,3 \mathrm{~cm}} \ln \frac{13,1 \mathrm{~cm}}{7,83 \mathrm{~cm}}}=40,69 \mathrm{~cm}=0,4069 \mathrm{~m}$

a rezonancia frekvencia: $f_{0}=\frac{c}{\lambda_{0}}=\frac{3 \cdot 10^{\mathrm{s}} \mathrm{m} / \mathrm{s}}{0,4059 \mathrm{~m}}=7,373 \cdot 10^{\mathrm{s}} 1 / \mathrm{s}=737,3 \mathrm{MHz}$

A generátorból (magnetronból) kilépő teljesítmény haladó hullám formájában belép a négyszögletes csőtápvonalba és a rezonátoron kialakított gerjesztő-résen terjed tovább a rezonátor zárt terébe. A rezonátorban lévő közeg - dielektromos tulajdonságainak megfelelően - módosítja a rezonátorban és a tápvonalban a kialakuló erővonalképet, illetve energiát vesz fel az elektromágneses térböl.

A hangoló rúd a tápvonal szélesebbik oldalának szimmetriatengelyében van elhelyezve és menetes kialakítása révén különböző mértékig hatolhat be a tápvonal villamos terébe, ahol a behatolás értékétől függően kapacitív vagy induktív reaktanciát képvisel a tápvonal impedanciájában. Ha például a terhelés kapacitív jellegü, a hangoló rúd állitásával induktív 
reaktanciát kell becsatolni a térbe, azaz beállíthatunk egy olyan értéket, ahol a két reaktancia kompenzálja egymást és a valós, ohmos impedancia marad terhelésként. Ekkor minimális lesz a visszavert jel, melyet a méröüreggel mérhetünk. Ảltalában a terhelés reaktanciája különböző mértékủ fáziseltolást hoz létre, melyet egy hangoló rúddal már nem lehetséges kompenzálni, ezért három, egymástól számitott távolságra elhelyezett hangoló rúd a megoldás.

2. ábra: A mikrohullámú gerjesztö egység és a toroid-rezonátor

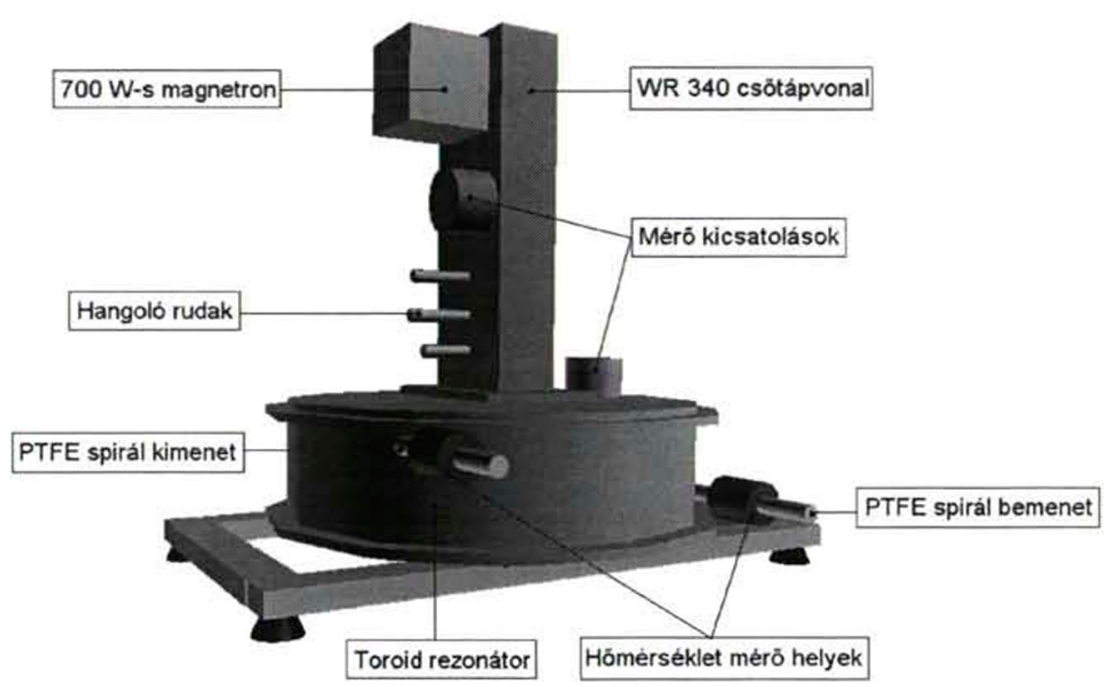

Készitette: Ludányi Lajos

A készülékben az anyagtovábbítást egy pneumatikus mágnes szeleppel vezérelt pneumatikus munkahenger végzi. A kezelörendszerben lehetöség van golyós szelepekkel többféle anyagtovábbítási ciklus választására (pl.: töltési, ürítési, keringtetési, stb.), illetve ezeken túlmenően egyéb lehetőségeket is nyújt a rendszer. A kezelt anyag hőmérsékletfelfutásának szabályozhatóságára egy hütőegység került beépitésre a toroidrezonátor után. A kezelt anyag térfogatáramát egy áramlásmérő méri, melynek villamos jelét, illetve az iszap be-és kimeneti hömérsékleteit egy mérés-adatgyüjtő fogadja, majd szoftveresen, on-line módon rögzíti, illetve a számítógép képernyöjén megjeleníti. $\mathrm{Az}$ üregrezonátorból egy mérőfejen keresztül kicsatolt mikrohullámú jelet a mikrohullámú teljesítménymérő feldolgozza és a mért teljesítménnyel arányos DC jelet szintén a mérésadatgyüjtőn keresztül rögzíthetjük, illetve jelenithetjük meg a számítógépen. Az adatgyüjtő szabad méröhelyei lehetőséget nyújtanak az adott kezelési feladatnak megfelelő további paraméterek ( $\mathrm{pl}$ : $\mathrm{pH}$, vezetöképesség, oldott oxigéntartalom, turbiditás, stb.) mérésére.

\section{3. ÖSSZEFOGLALÁS/KÖVETKEZTETÉSEK/EREDMÉNYEK}

A kifejlesztett kezelörendszeren elvégzendő további feladataok: a mikrohullámú kezelés, müveleti-, eljárás- és berendezés paramétereinek definiálása, amelyek alkalmasak a folyamat közben a hömérséklettöl és a kezelt anyag fiziko-kémiai tulajdonságainak változásaitól függő folyamatok nyomonkövetésére és leírására, a meghatározott paraméterek 
alkalmazásával a folyamat energetikai szempontú optimálása, fiziko-matematikai modell alkotása, amely alapján kidolgozható a berendezés léptéknövelési algoritmusa.

\section{IRODALOMJEGYZÉK}

Beszédes, S., Kertész, Sz, László, Zs., Szabó, G., Hodúr, C. (2009): Biogas production of ozone and/or microwave-pretreated canned maize production sludge. Ozone Sci. \& Eng. J. 31 (3), 257-261.

Beszédes S., László Zs., Horváth H. Zs., Szabó G., Hodúr C. (2011.,a): Comparison of the effects of microwave irradiation with different intensities on the biodegradability of sludge from the dairyand meat-industry. Bioresource Technology , 102, pp.: 814-821

Beszédes S., Ludányi L., Koltai A., Szabó G. (2011.,b): Toroid-rezonátor fejlesztése szennyviziszapok mikrohullámú kondicionálásra (Development of toroid cavity resonator for microwave conditioning of wastewater sludge). 7. Magyar Száritási Szimpózium. Gödöllö, Magyarország, 2011.04.07-2011.04.08 Gödöllö: Szent István Egyetem, pp. 12-13.(ISBN:978-963269-211-1)

Eskicioglu, C., Prorot, A., Marin, J., Droste R.L., Kennedy, K.J. (2008): Synergetic pretreatment of sewage sludge by microwave irradiation in presence of $\mathrm{H}_{2} \mathrm{O}_{2}$ for enhanced anaerobic digestion. Water Res. 42, 4674- 4682.

Eskicioglu C., Kennedy K.J., Droste R.L. (2009): Enhanced disinfection and methane production from sewage sludge by microwave irradiation. Desalination 278, 279-285.

Guo L., Li, X.M., Bo, X., Yang, Q., Zeng, G.M., Liao, D.X., Liu, J.J. (2008): Impacts of sterilization, microwave and ultrasonication pretreatment on hydrogen producing using waste sludge. Biores. Technol. 99, 3651-3658.

Houdkova L., Boran J., Ucekaj V., Elsasser T., Stehlik (2008): Thermal processing of sewage sludge II. Applied Thermal Eng. 28, 2083-2088.

Müller, J., Winter, A., Strünkmann, G. (2004): Investigation and assessment of sludge pretreatment processes. Water Sci. Technol. 49 (10), 97-104.

Pino-Jelcic, S.A., Hong, S.M., Park, J.K. (2006): Enhanced anaerobic biodegradability and inactivation of fecal coliforms and salmonella ssp. in wastewater sludge by using microwaves. Wat. Environ. Res. 78(2), 209-216.

Szabó, G., Rajkó, R., Neményi, M., Hodúr, C. (2002): Modelling of Combined Hot-air Convective and Microwave Drying of Mushroom (Agaricus Bisporus). International Drying Symposium. IDS'2002. Beijing, August 27-30. China. Drying 2002. Edited by: C.W. Cao., Y.K. Pan., X.D. Liu., Y.X. Qu. Series Editor: A.S. Mujumdar. Volume A pp. 319-326. 